\title{
Sakubitril/valsartan MRA kullananlarda ilave klinik yarar sağlar mı? Hiperkalemi riskini artırır mı?
}

\author{
Dr. Barış Kılıçaslan
}

Sağlık Bilimleri Üniversitesi, İzmir Tepecik Eğitim ve Araştırma Hastanesi, Kardiyoloji Kliniği, İzmir

Mineralokortikoid reseptör antagonistlerinin (MRA), semptomatik düşük ejeksiyon fraksiyonlu kalp yetersizliği (DEFKY) olan hastalarda ölüm ve hastaneye yatış oranlarını azalttığ 1 bilinmektedir. ${ }^{[1]}$ Günümüz tedavi kılavuzları MRA'ları, beta-bloker ve renin anjiyotensin aldosteron sistemi inhibitörleri (RAASÍ) ile tedaviye rağmen semptomatik olan hastalarda önermektedir. ${ }^{[2]}$ Fakat MRA'lar özellikle kronik böbrek yetersizliği (KBY) olan hastalarda hiperkalemiye neden olabileceklerinden ötürü kullanımları sınırlanmaktadır. Buna bağlı olarak klinik pratikte endikasyonu olan hastalarda dahi yeterli kullanılmamaktadır. ${ }^{[3]}$

Sakubutril-Valsartan DEFKY hastalarında kullanım endikasyonu aldığında, MRA'lar ile birlikte kullanımı ile ilgili böbrek disfonksiyonu ve hiperkalemiyi artırabileceğine dair şüpheler dile getirilmekteydi. PARADIGM-HF çalışmasında MRA'ların kullanımı araştırmacıların takdirine bırakılmış, tolere edilirse devamı ve kullanmayanlarda da gerekirse başlanması teşvik edilmiştir. PARADIGM-HF çalışmasında randomize edilen 8399 hastanın 4671'i (\%55.6) MRA kullanırken, bunlarında 2271'si sakubitril-valsartan grubuna randomize edilmişti. PARADIGM HF sonuçları; MRA kullanan ve kullanmayan olguların enalapril ile karşılaştırıldığında sakubitril/ valsartan'dan primer sonlanım (KV ölüm veya KY hospitalizasyon) ve tek başına KV ölüm açısından benzer oranda fayda gördüğünü gösterdi (sırasıyla $p$ etkileşim değeri 0.10 ve 0.32$).{ }^{[4]}$

Güncel k1lavuzların önerisine göre PARADIGM HF çalışmasında \%83.4 hasta MRA tedavisi için uygunken, sadece \%55.6 hasta MRA tedavisi almakta idi. A. Desai ve arkadaşlarının MRA'ların enalapril veya sakubutril/valsartan ile kullanımının hiperkalemi üzerine etkisini araştırdıkları PARADIGM-HF çalışmasının subgrub analizinde, sakubitril/valsartan tedavisinin MRA kullanımından bağımsız olarak KV ölüm riskini azalttığı ortaya kondu (MRA kullanmayanlar: HR, 0.75 [\%95 CI, 0.63-0.89]; MRA kullananlar: HR, 0.84 [\%95 CI, 0.73-0.98]; p etkileşim değeri=0.30). ${ }^{[5]}$ Aynı subgrup analizi çalışma ilacından bağımsız olarak MRA kullanan hastalarda, kullanmayanlara göre hiperkalemi insidansının (serum potasyum $>5.5 \mathrm{mEq} / \mathrm{L})(10.0$ vs 7.3 per 100 hasta y1li; HR, 1.33 [\%95 CI, 1.19-1.48]; $\mathrm{p}<0.001)$ ve ciddi hiperkaleminin (serum potasyum $>6 \mathrm{mEq} / \mathrm{L})(2.7$ vs 2.0 per 100 hasta y1li; HR, 1.35 [\%95 CI, 1.111.64]; $\mathrm{p}=0.003$ ) daha fazla olduğunu saptamışlardır. Başlangıçta MRA kullanmayan hastalarda hiperkalemi ve ciddi hiperkalemi görülme sıklığı sakubitril/ valsartan ve enalapril alan hastalarda benzer saptanmıştır (Tablo 1). Bazalde MRA kulllanan hastalarda hiperkalemi görülme sıklığı tedavi grublarında benzerken (10.6 vs 9.4 per 100 hasta yıl1; HR, 1.12 [\%95 CI, 0.98-1.28]; $\mathrm{p}=0.11$; risk difference, 1.2 per 100 hasta y1l1 [\%95 CI, -0.1 to 2.6 per 100 hasta y1l1], ciddi hiperkalemi görülme siklığ1 enalapril kullananlarda daha fazla saptanmıştır. (3.1 vs 2.2 per 100 hasta y1li; HR, 1.37 [\%95 CI, 1.06-1.76]; p=0.02; risk farkı, 1.0 per 100 hasta yılı [\%95 CI, 0.3-1.6 per 100 hasta yıl1] (Tablo 1). Enalapril ile artan hiperkalemi riski, MRA ile tedavi edilen hastalarda tedavi edilmeyen hastalardan biraz daha yüksek olmasına rağmen, hiperkalemi riski ile ilgili olarak başlangiçta tedavi alan ve takiplerde MRA başlanan hastalar arasında istatistiksel bir etkileşim saptanmamıştır. Her iki grupta da ileri hiperkalemi enalapril alanlarda sakubitril/valsartan alanlara göre anlamlı olarak daha yüksek saptanmıştır (3.3 vs 2.3 per 100 hasta-y1li; HR, 1.43 [\%95 CI, 1.13-1.81]; p=0.003). Sonuç olarak PARADIGM-HF çalışmasında MRA kullanan hastalarda ciddi hiperkalemi $(>6.0 \mathrm{mEq} / \mathrm{L})$ sıklığı daha yüksek saptanmış fakat MRA'ların sakubitril/valsartan ile beraber kullanımı enaraprile göre bu riski azaltmıştır. ${ }^{[5]}$ 


\begin{tabular}{|c|c|c|c|c|c|c|c|c|}
\hline MRA kullanımı & Enalapril & İnsidans ${ }^{a}$ & $\begin{array}{l}\text { Sakubutril- ì } \\
\text { valsartan }\end{array}$ & nsidans $^{a}$ & $\begin{array}{c}\text { HR } \\
\text { (Ena.vs SV) }\end{array}$ & $\mathrm{p}$ & $\begin{array}{c}\text { HR } \\
\text { (Ena.vs SV) } \\
(95 \% \mathrm{Cl})\end{array}$ & $\mathrm{p}$ \\
\hline \multicolumn{9}{|l|}{ MRA (-) } \\
\hline Hiperkalemi ${ }^{b}$ & 278 (\%15.3) & 7.4 & $288(\% 15.0)$ & 7.21 & $1.02(0.87-1.20)$ & 0.81 & $1.08(0.91-1.28)$ & 0.39 \\
\hline Ciddi hiperkalemic & $90(\% 5.0)$ & 2.2 & $78(\% 4.1)$ & 1.81 & $1.23(0.91-1.67)$ & 0.17 & $1.30(0.96-1.78)$ & 0.09 \\
\hline \multicolumn{9}{|l|}{ MRA (+) } \\
\hline Hiperkalemi ${ }^{b}$ & $488(\% 18.7)$ & 10.6 & $386(\% 17.0)$ & 9.41 & $1.12(0.98-1.28)$ & 0.11 & $1.12(0.97-1.29)$ & 0.11 \\
\hline Ciddi Hiperkalemic & $146(\% 6.1)$ & 3.1 & $103(\% 4.5)$ & 2.21 & $1.37(1.06-1.76)$ & 0.02 & $1.41(1.09-1.83)$ & $<0.01$ \\
\hline
\end{tabular}

a: 100 hasta-yıl başına düşen hasta; b: $5.5 \mathrm{mEq} / \mathrm{L}$ dan yüksek potasyum düzeyi; c: $6.0 \mathrm{mEq} / \mathrm{L}$ dan yüksek potasyum düzeyi. MRA: Mineralokortikoid antogonisti; Ena.: Enapril; SV: Sakubutril-valsartan; PARADIGM-HF: Prospective Comparison of ARNI With an ACE-Inhibitor to Determine Impact on Global Mortality and Morbidity in Heart Failure.

MRA'ların DEFKY'de ispatlanmış faydalarına ve kılavuz önerilerine rağmen, RAASİ ile beraber kullanımı böbrek yan etkilerinden ve özellikle de hiperkalemiden çekinildiğinden sınırlı kalmaktadır. PARADIGM-HF çalışmasından elde edilen bu veriler, MRA'ların DEFKY hastalarında RAASİ ile kombine edildiğinde neprilisin inhibisyonunun hiperkalemi riskini azalttığını göstermektedir. Sonuç olarak, DEFKY'li uygun hastalarda sakubitril/valsartan kullanımı, MRA'ların güvenli bir şekilde kullanım sıkl1$\breve{g} 1 n ı$ artıracaktır. Sakubitril/valsartanın faydalanımının MRA kullanımından bağımsız olduğu saptansa da, hastalarda kılavuzların önerdiği şekilde sakubutril/ valsartan ve MRA'nın beraber kullanım motivasyonunu artıracağı için DEFKY tedavisinde ilave klinik yarar sağlanacağı aşikardır.

\section{Kaynaklar}

1. Pitt B, Zannad F, Remme WJ, Cody R, Castaigne A, Perez A, Palensky $\mathrm{J}$, Wittes $\mathrm{J}$. The effect of spironolactone on morbidity and mortality in patients with severe heart failure. Randomized Aldactone Evaluation Study Investigators. N Engl J Med. 1999 Sep 2;341(10):709-17.

2. Yancy CW, Jessup M, Bozkurt B, Butler J, Casey DE Jr, Drazner MH, et al. 2013 ACCF/AHA guideline for the management of heart failure: a report of the American College of Cardiology Foundation/American Heart Association Task Force on Practice Guidelines. J Am Coll Cardiol 2013;62:e147-239.

3. Dev S, Lacy ME, Masoudi FA, Wu W-C. Temporal trends and hospital variation in mineralocorticoid receptor antagonist use in veterans discharged with heart failure. J Am Heart Assoc 2015;4:e002268.

4. McMurray JJ, Packer M, Desai AS, Gong J, Lefkowitz MP, Rizkala AR, et al. Angiotensin-neprilysin inhibition versus enalapril in heart failure. N Engl J Med 2014;371:993-1004.

5. Desai AS, Vardeny O, Claggett B, McMurray JJ, Packer M, Swedberg K, et al. Reduced Risk of Hyperkalemia During Treatment of Heart Failure With Mineralocorticoid Receptor Antagonists by Use of Sacubitril/Valsartan Compared With Enalapril: A Secondary Analysis of the PARADIGM-HF Trial. JAMA Cardiol 2017;2:79-85. 